\title{
ÖNGYILKOSSÁG-PREVENCIÓ AZ ISKOLÁKBANः A FiatalKori Mentális EgészsÉg-ÖNTUdATOSSÁG Program (YAM) Bemutatása
}

\author{
BALÁZS JUDIT
}

\author{
ELTE PPK Pszichológia Intézet, Fejlődés- és Klinikai Gyermekpszichológia Tanszék, Budapest \\ Bjørknes University College, Oslo
}

A cikk bevezetőjében a fiatalkori öngyilkosság témájával ismerteti meg az olvasót, röviden összefoglalja: 1) a fontosabb idevonatkozó epidemiológiai adatokat - melyekből látható a téma fontossága, 2) a rizikó-, és védőfaktorokat - melyek rávezetik az olvasót, hogy mire kell figyelni a megelőzés érdekében, és 3) a prevenciós módszereket. A téma elhelyezése után egy validált, bizonyítottan hatékony, magyar nyelven elérhető, hazánkban adaptált, iskolában megvalósitható mentális egészségfejlesztő és öngyilkosság megelözö program, a Fiatalkori Mentális Egészség-öntudatosság Program (Youth Aware of Mental Health Programme: YAM) kerül bemutatásra. Miután az iskola igen fontos színtere a prevenciónak, fontosnak tartjuk, hogy egy ilyen paraméterekkel jellemezhető program beépüljön a hazai iskolák kurrikulumába és minden fiatal számára elérhető legyen.

Kulcsszavakः fiatalkori öngyilkosság, rizikófaktorok, védőfaktorok, iskolai prevenció, YAM

The introduction of the article briefly summarizes the topic of youth suicide and: 1) the most relevant epidemiological data that illustrates the importance of the topic, 2) the risk and protective factors that guide the reader to the prevention and 3) prevention methods. The next part of the article presents a validated, evidence based, school-based mental health promotion and suicide prevention program, the Youth Aware of Mental Health Program (YAM), which is already adopted into Hungarian schools. As the schools are very important place for prevention, we would like to highlight the importance that a prevention program with such parameters has to be integrated into the curriculum of the schools in Hungary and to make it accessible to all young people.

Keywords: youth suicide, risk factors, protective factors, school prevention, YAM

Levelező szerző: Balázs Judit, ELTE PPK Fejlődés- és Klinikai Gyermekpszichológia Tanszék, 1064 Budapest, Izabella utca 46. E-mail: balazs.judit@ppk.elte.hu 


\section{Fiatalkori öngyilkosság}

\section{Fiatalkori öngyilkosság - epidemiológia}

\section{A} fiatalkori öngyilkosságok száma a világban nőtt az elmúlt évtizedekben, a 1519 éves korosztálynál ez a második leggyakoribb halálok a közlekedési balesetek után (WHO 2018). A globális fiatalkori öngyilkossági rátával ellentétesen hazánkban csökkenést mutatott, de így is magasak a számok, pl. 2016-ban a 10-19 éves korosztályban 25 (nagyságrendileg egy egész osztály), míg a 20-29 éves korosztályban 101 fiatal halt meg öngyilkosság miatt (Egészségügyi Statisztikai Évkönyv 2018, WHO 2018).

Az öngyilkossági kísérletek előfordulási gyakorisága, amennyiben idesoroljuk a szándékos önsértést is, 10-100-szorosa a befejezett öngyilkosságoknak. Szándékos önsértés történhet öngyilkossági és nem öngyilkossági céllal (Horváth-Mészáros-Balázs 2015). Utóbbi jelenség leírására a pszichiátriai betegségek meghatározását leíró legújabb klaszszifikációs rendszer, a Diagnostic and Statistical Manual 5. kiadása (DSM-5) megjelenésével hivatalossá vált szakkifejezés a "nem szuicidalis önsértés” (non-suicidal self-injury, NSSI), ami a DSM-5 „További kutatást igénylo állapotok” fejezetébe bekerült (American Psychiatric Association 2013).

Az American Association of Suicidology (2017) jelentése szerint egy év alatt a középiskolás diákok 20\%-a komolyan gondolkozik azon, hogy öngyilkos legyen. Első éves „college” diákoknál történt felmérés szerint az öngyilkossági gondolatok élettartam előfordulási gyakorisága 32,7\%, az öngyilkossági tervé 17,5\%, míg az öngyilkossági kísérleté 4,3\%, továbbá azt az eredményt kapták, hogy akiknek az életében előfordult öngyilkos magatartás, azok háromnegyedénél ez először már 16 éves koruk előtt jelentkezett (Mortier et al. 2018).

\section{Fiatalkori öngyilkosság - rizikó-, és védőfaktorok}

Öngyilkosságot elkövető, illetve megkísérlő fiataloknál - felnőttekhez hasonlósan - több mint 90\%-ban fennáll valamilyen pszichiátriai betegség (Balázs et al. 2003; Gould et al. 2003), és csupán 5-20\%-uk áll ekkor pszichiátriai kezelés alatt (Marttunen-Pelkonen 2000). Az öngyilkosságot elkövető, megkísérlő gyermekeknél/felnőtteknél leggyakoribb pszichiátriai betegség a depresszió, a második leggyakoribb ok a pszichoaktív szerhasználat, a harmadik pedig fiataloknál a viselkedészavar, felnőttkorban a szkizofrénia (Cherpitel-Borges-Wilcox 2004; Fleischmann et al. 2005).

További öngyilkossági rizikót jelentenek a pszichiátriai betegségek mellett, gyakran azokkal szövődve minden korosztálynál - így a fiataloknál is - a negatív életesemények. Ezekre példa gyermekkorban a családban levő nehézségek (pl. ha rossz a szülö-gyermek kapcsolat, sok a családban a feszültség, a szülők válása, a bántalmazás), a kortárskapcsolati gondok (pl. ha valakinek nincsenek barátai, a szakítás, a bullying [zaklatás]), és az iskolai kudarcok (Mayes et al. 2014; Ribmer et al. 2009).

Fontos megemlíteni az öngyilkossági rizikófaktorok sorában - szintén minden korosztálynál - azt, hogy ha valaki korábban már megkísérelt öngyilkosságot (Hawton-Van Heeringen 2009). A befejezett öngyilkosságot elkövetők közel harmada kísérelt meg korábban öngyilkosságot (Arató et al. 1988). 
Az öngyilkosság kérdését számos tévhit lengi körül, pl. aki „csak” kísérletezik, úgysem akar meghalni. Ez látható a fenti adatból, hogy nem igaz. Minthogy az sem, hogy aki beszél az öngyilkossági terveiről, „igazából” nem is akar meghalni. Nagyon fontos, hogy ha valaki beszél arról vagy utal rá, hogy szeretne meghalni, vagy beszámol öngyilkossági terveiről, búcsúlevelet ír (pl. „Úgyis könnyebb lenne mindenkinek nélkülem; „Hamarosan kiszállok az egészből”), azt nagyon komolyan kell venni, szakemberhez irányítani, mert ezek már az öngyilkosság figyelmeztető jelei lehetnek.

Az öngyilkosságnak számos védőfaktora is ismert. Egyénben rejlő védőfaktor a jó problémamegoldó képesség, az optimizmus, a rendszeres sportolás, a vallásosság, azonban ha valaki depressziós lesz, a felsoroltak, illetve ezek hatása jelentősen károsul a depresszió tüneteiből adódóan (Ribmer-Fekete 2012). Ezért kiemelten fontos „védőfaktora” az öngyilkosságnak, ha valaki a pszichiátriai betegségére megkapja az adekvát kezelést. Családban rejlő védőfaktor a jó szülő-gyermek kapcsolat, míg társadalmi szinten levő védőfaktor, ha a pszichés zavarokat nem stigmatizálják, ha az egészségügy könnyen elérhető, és ha müködnek prevenciós programok (pl. iskolákban) (Balázs-Kapornai 2012; Balázs 2015).

\section{Fiatalkori öngyilkosság-megelöző programok}

Mint fentebb szerepel, az öngyilkosság nagyon fontos rizikófaktorai a kezeletlen pszichiátriai betegségek (Balázs et al. 2003; Gould et al. 2003), ezért az öngyilkosság megelőzésének minden korosztálynál, így fiataloknál is legfontosabb lépése a pszichiátriai betegségek korai felismerése, a segítségre szoruló gyerekek/felnőttek szakemberhez juttatása és megfelelő kezelése.

A kapuör (gatekeeper) programok lényege pont az, hogy a társadalom számos csoportjának, pl. fiatalok esetében a szülőknek, házigyermekorvosnak és a pedagógusoknak a szakemberek képzést tartanak arról, hogy hogyan ismerhetik fel az öngyilkosság figyelmeztető jeleit, és ilyenkor mi a teendő (Balázs 2015; Balázs-Kapornai 2012; Hegerl et al. 2009; Szántó et al. 2007). Ezeket a programokat időről időre ismételni kell, hogy hatékonyságuk fennmaradjon.

A kortárs segitőknek nagy szerepük van az öngyilkosság-megelőzésben minden korosztálynál, de különösen serdülökorban, mert a fiatalok általában nagyobb bizalommal vannak a kortársaik, mint a felnőttek felé (Balázs-Kapornai 2012). A lelkisegély telefonszolgálatoknak szintén ismert a jelentős öngyilkosság-megelőző szerepük (VijayakumarArmson 2005).

A média szerepét is meg kell említeni az öngyilkosság-megelőzésben. A média segítheti, hogy a társadalomban ne legyen stigma, ha valakinek pszichiátriai betegsége van, illetve hogy az embereknek nagyobb tudásuk legyen az öngyilkosság rizikófaktorairól és figyelmeztető jeleiről, illetve arról, hogy hová forduljanak a bajban levők (SchmidtkeSchaller 2000). Azonban a média fokozhatja is az öngyilkossági rizikót, ugyanis pl. a szenzációhajhász hírközlés egy „celeb” öngyilkosságáról az erre esékenyekben (pl. depresszióban szenvedők), különösen serdülöknél fokozhatja az öngyilkosság rizikóját. Ezért dolgozott ki a WHO számos szervezettel együtt médiaajánlást arról, hogy hogyan közöljenek a szakemberek mértéktartóan az öngyilkosságról híreket (Schmidtke-Schaller 2000; Nemzeti Média és Hírközlési Hatóság 2012). 


\section{Iskolai öngyilkosság-megelőző programok}

$\mathrm{A} z$ iskola a prevenciós programok fontos színtere gyermek-, és serdülőkorban, hiszen ez a korosztály sok időt tölt itt kötelezően, így egyszerre sok gyermek/serdülő és pedagógus könnyen elérhető (Gould et al. 2009; Scott et al. 2009).

$\mathrm{A} z$ iskolákban a fent ismertetett prevenciós programok közül a kapuőr program pedagógusoknak ajánlott. Ezeknek lényege, hogy pedagógusok megtanulják egy képzés során, hogy hogyan ismerhetik fel diákjaiknál a fokozott öngyilkossági rizikót és ekkor mit tegyenek (Balázs-Kaporna 2012; Gould et al. 2003).

Szintén iskolai keretek között zajló prevenciós módszer, ha a pszichológus vagy pszichiáter szakemberek direkt szürik az iskolában a pszichés problémájú, öngyilkossági rizikójú fiatalokat és továbbirányítják őket a szüleik bevonásával szakellátásba (Gould et al. 2009).

Iskolai megelőző programok nagy csoportja maguknak a fiataloknak tartott képzési programok arról, hogy hogyan ismerik fel önmagukban vagy barátjuknál, osztálytársuknál, ha pszichés problémájuk van és/vagy öngyilkossági rizikó áll fenn, és ilyenkor mit csináljanak. Az ilyen programok akkor hatékonyak, ha beépülnek a kurrikulumba (Portzky-Heeringen 2006).

\section{A Fiatalkori mentális egészség-öntudatosság program (Youth Aware of Mental Health Programme: YAM) bemutatása}

\section{A YAM menetének ismertetése}

A YAM 14-16 éves fiataloknak szóló iskolai keretek között zajló egészségfejlesztő, öngyilkosság-megelőző program (Balázs 2017; Wasserman et al. 2012). A YAM a fiatalok mentális egészségről szóló tudásának és énhatékonyságának növelését tűzi ki célul, mely elvezet oda, hogy a fiatalok nyitottabbak lesznek a problémák felismerésére és megoldására, beleértve az öngyilkosságot is.

A programot erre kiképzett két szakember tartja egy osztálynak, akik függetlenek az iskolában dolgozó pedagógusoktól, ezzel is segítve a fiatalokat abban, hogy meg tudjanak nyílni. A YAM 6×45 perc iskolai tanórán át tart, ami 4 héten oszlik el (Wasserman et al. 2012). Az 1. táblázat bemutatja a YAM program felépítését.

1. táblázat: A YAM program felépítése

\begin{tabular}{lcl}
\hline Alkalmak & Időtartam(perc) & Tematika \\
\hline 1. hét & 45 & $\begin{array}{l}\text { + nyitóelőadás } \\
\text { + fiataloknak prospektus és névjegykártya kiosztása } \\
\text { + poszterek kihelyezése az osztálytermekbe }\end{array}$ \\
\hline 2. hét & 90 & + szerepjátékok \\
\hline 3. hét & 90 & + szerepjátékok \\
\hline 4. hét & 45 & + záróelőadás \\
\hline
\end{tabular}


Az első alkalom 45 perces, amikor a fiatalok meghallgatnak egy nyitó előadást, ami az alábbi témákat érinti:

- Lelki egészség tudatosan

- Tanácsok, hogy segíts magadon

- Stressz és krízis

- Depresszió és öngyilkossági gondolatok

- Segítségnyújtás egy gondban levő barátnak

- Tanácskérés: kihez fordulhatsz

Az előadás tematikájának megfelelő prospektust is kapnak a fiatalok, és a tantermekben elhelyeznek a szakemberek 6 posztert. Ezek segítik az előadáson elhangzott információk elmélyítését, és a fiatalok tudják ezeket a program lezárulása után is használni (Wasserman et al. 2012). Szintén az első alkalmon kap minden fiatal egy névjegykártyát, melyen egy "kapcsolattartó” és egy gyermekpszichiátriai ellátó intézmény napi 24 órás elérhetősége szerepel. Így, ha a fiatal úgy érzi a YAM programban elhangzottak alapján, hogy segítségre van szüksége, tud hova fordulni (Wasserman et al. 2012).

A második és harmadik alkalom 90-90 perces, mely az osztálytermek átrendezésével kezdődik, majd a szakemberek szerepjátékoznak a fiatalokkal az alábbi három témakörben:

- döntésekkel kapcsolatos tudatosság,

- optimális stresszkezelés,

- depresszió és öngyilkossági gondolatok.

A szerepjátékok az egyszerübbtől a nehezebb élethelyzetekig haladnak. A szerepjátékok során a fiatalok stresszkezelő, problémamegoldó, érzelemkifejező és empatikus képessége fejlődik. További fontos funkciója a szerepjátékoknak, hogy ezek során a fiataloknak lehetőségük nyílik biztonságos környezetben átgondolni különböző, nem könnyü élethelyzeteket (pl. kortárs nyomás, szülők válása, iskolaváltás, bullying, depreszszió, öngyilkossági gondolatok), így ha esetleg később ilyenekkel „élesben” találkoznak, akkor a YAM program során megtanult képességeik alapján jobban tudnak reagálni. Egy-egy szerepjáték után a fiatalok átbeszélik egymással és a szakemberekkel, hogy hogyan látják a szerepjátékban történeteket, az egyes szereplőket és milyen más konstruktív megoldást tudnának még javasolni az adott élethelyzetben (Wasserman et al. 2012).

A negyedik alkalommal egy 45 perces interaktív előadás zárja a YAM programot, melynek során újra végigbeszéli a szakember a fiatalokkal a nyitóelőadáskor elhangzott 6 témát, most már a fiatalok szerepjátékok során szerzett személyes élményeivel, tapasztalataival (Wasserman et al. 2012).

\section{A YAM validálásának ismertetése}

A YAM programot a Karolinska Institutet (Svédország) koordinálásával, EUFP7-es támogatott együttműködés keretében, a „Fiatalok életének megmentése és szerepvállalásuk/önállóságuk növelése Európában” (Saving and Empowering Young Lives in Europe: SEYLE) vizsgálat során dolgozta ki kutatócsoportunk egy nemzetközi csapattal (Wasserman et al. 2015). 
A vizsgálatba összesen 12 395, hazánkból 1009 serdülőt (14-16 éves) vontunk be. Háromféle prevenciós program - 1. szakemberek direkt szürnek, 2. tanároknak gatekeeper képzés és 3. a YAM-hatékonyságát vetettük össze egy kontrollcsoporttal, randomizált, kontrollált vizsgálat keretében. A SEYLE vizsgálatban etikai okokból a kontrollcsoportnál is történt egy ún. „minimális program”, ezért ezt „Tájékoztató programnak" nevezzük. Ennek során kitettük az osztálytermek falára a YAM programban is használt 6 posztert, valamint a serdülők itt is kaptak egy névjegykártyát egy „kapcsolattartó" és egy gyermekpszichiátriai ellátó intézmény napi 24 órás elérhetőségével. Azonban a YAM programtól eltérően itt a serdülőknek nem tartottunk előadást, nem kaptak prospektust és nem vontuk be őket szerepjátékokba, mint a YAM program során.

A háromféle intervenciós program közül a YAM program mellett mutatkozott szignifikáns csökkenés a 14-16 éves fiataloknál a 12 hónapos utánkövetéskor az öngyilkos magatartás előfordulási gyakoriságában a Tájékoztató programhoz képest (OR: 0,45, 95\% CI: 0,24-0,85, $p=0,014$ ), míg a másik két programnál nem (ProfSceen: OR: 0,65, 95\% CI: 0,36-1,18, $p=0,158$, QPR: OR: 0,70, 95\% CI: 0,39-1,25, $p=0,229$ ) (Wasserman et al. 2015).

A számszerü adatok mellett nagyon fontos, hogy mind a nemzetközi, mind a hazai tapasztalataink alapján a fiatalok körében a YAM kifejezetten pozitív fogadtatásban részesült, lelkesen vettek részt a programban, a szerepjátékokban, ezek megbeszélésébe aktívan bekapcsolódtak, sőt tudunk olyan osztályról, ahol a fiatalok a YAM program hivatalos lezárása után, maguktól folytatták a hasonló tematikájú, struktúrájú közös alkalmakat (Balázs 2017).

A validálás lezárása után a YAM programot már több országban az iskolai kurrikulum kötelező részévé tették.

\section{Összefoglalás}

Összefoglalásként kiemelnénk, hogy a fiatalkori öngyilkosságok megelőzése fontos kérdés. Bizonyítottan hatékony, iskolai keretek között történő megelőző program a YAM, melynek nemzetközi és hazai adaptációja során kapott visszajelzések alapján igen pozitív a fogadtatása a fiatalok között. Mindezért fontos a YAM program bevezetése a hazai iskolákba is, hogy minden fiatal részesülhessen bizonyítottan hatékony öngyilkosságmegelözésben felnövekedése során.

Köszönetnyilvánítás: A SEYLE vizsgálatot az Európai Unio FP7 keretprogramja támogatta, grant szám: HEALTH-F2-2009-223091. A SEYLE Projekt vezetője Prof. Danuta Wasserman (Karolinska Insitute, National Centre for Suicide Research and Prevention of Mental Ill-Health [NASP/KI] Stockholm, Svédország). Az Executive Committee tagjai: Prof. Danuta Wasserman, Vladimir Carli (mindketten: NASP/KI, Svédország), Prof. Marco Sarchiapone (University of Molise, Campobasso, Olaszország), Professor Christina W. Hoven, Camilla Wasserman (mindketten: Columbia University and New York State Psychiatric Institute, NY, USA). A SEYLE konzorcium tagjai: Danuta Wasserman (NASP/KI, Svédország), Christian Haring (Ausztria), Airi Varnik (Észtország), Jean-Pierre Kahn (Franciaország), Romuald Brunner (Németország), Balázs Judit (Magyarország), Paul Corcoran (Írország), Alan Apter (Izrael), Marco 
Sarchiapone (Olaszország), Doina Cosman (Románia), Vita Postuvan (Szlovénia) és Julio Bobes (Spanyolország).

A magyarországi SEYLE munkacsoport tagjai: Balázs Judit, Bálint Mária, Farkas Luca, Horváth Lili Olga, Keresztény Ágnes, Mészáros Gergely, Szentiványi Dóra.

\section{IRODALOM}

American Association of Suicidology (2017) Youth Suicide Fact Sheet. http://www. suicidology.org/resources/facts-statistics [Letöltve: 2017. 11. 01.]

American Psychiatric Association (2013) Diagnostic and Statistical Manual of Mental Disorders, 5th edn. (DSM-5). Washington DC, American Psychiatric Association.

Arató M., Demeter E., Rihmer Z. \& Somogyi E. (1988) Retrospective Psychiatric Assessment of 200 Suicides in Budapest. Acta Psychiatrica Scandinavica, 77, pp. 454456.

BALÁzs J. (2015) Öngyilkos magatartás zavara és nem-szuicidális önsértés. In: BALÁzs J. \& MıкLósi M. (eds) Gyermek-és ifjúkor pszichés zavarainak tankönyve. Budapest, Semmelweis Kiadó és Multimédia Stúdió. pp. 185-190.

BALÁzs J. (2017) Serdülőkori mentális egészségfejlesztő program a középiskolákban: A YAM program bemutatása. Gyermekgyógyászat, 68, pp. 352-357.

Balázs J. \& Kapornai K. (2012) Öngyilkosság gyermek- és serdülőkorban. In: Kalmár S., Németh A. \& Rihmer Z. (eds) Az öngyilkosság orvosi szemmel. Budapest, Medicina. pp. 124-136.

Balazs, J., Lecrubier, Y., Csiszer, N., Kosztak, J. \& Bitter, I. (2003) Prevalence and Comorbidity of Affective Disorders in Persons Making Suicide Attempts in Hungary: Importance of the First Depressive Episodes and of Bipolar II Diagnoses. Journal of Affective Disorders, 76, pp. 113-119.

Cherpitel, C. J., Borges, G. L. \& Wilcox, H. C. (2004) Acute Alcohol Use and Suicidal Behavior: A Review of the Literature. Alcoholism: Clinical and Experimental Research, Vol. 28. No. 5. Suppl. pp. 18-28.

Egészségügyi Statisztikai Évkönyv 2016. (2018) Budapest, Központi Statisztikai Hivatal.

Fleischmann, A., Bertolote, J. M., Belfer, M. \& Beautrais, A. (2005) Completed Suicide and Psychiatric Diagnoses in Young People: A Critical Examination of the Evidence. American Journal of Orthopsychiatry, 75, pp. 676-683.

Gould, M. S., Greenberg, T., Velting D. M. \& Shaffer, D. (2003) Youth Suicide Risk and Preventive Interventions: A Review of the Past 10 Years. Journal of the American Academy of Child and Adolescent Psychiatry, 42, pp. 386-405.

Gould, M. S., Marrocco, F. A., Hoagwood, K., Kleinman, M., Amakawa, L. \& Altschuler, E. (2009) Service Use by At-Risk Youths after School-based Suicide Screening. Journal of the American Academy of Child and Adolescent Psychiatry, 48, pp. 1193-1201.

Hawton, K. \& van Heeringen, K. (2009) Suicide. Review. The Lancet, 373, pp. 13721381.

Hegerl, U., Wittenburg, L., Arensman, E., Van Audenhove, C., Coyne, J. C., McDaid, D., van der Feltz-Cornelis, C. M., Gusmão, R., Kopp, M., Maxwell, M., Meise, U., Roskar, S., Sarchiapone, M., Schmidtke, A., Värnik, A. \& Bramesfeld, A. (2009) Optimizing Suicide Prevention Programs and Their 
Implementation in Europe (OSPI Europe): An Evidence-based Multi-level Approach. BMC Public Health, 23, 428.

Horváth L, Mészáros G., Balázs J. (2015) Serdülőkori nem-szuicidális önsértés: aktuális kérdések. Neuropsychopharmacologia Hungarica 17, pp. 1-9.

Marttunen, M. \& Pelkonen, M. (2000) Psychiatric Risk Factors for Adolescent Suicide: A Review. Psychiatry Fennica, 31, pp. 110-125.

Mayes, S. D., Baweja, R., Calhoun, S. L., Syed, E., Mahr, F. \& Siddiqui, F. (2014) Suicide Ideation and Attempts and Bullying in Children and Adolescents: Psychiatric and General Population Samples. Crisis, 35, pp. 301-309.

Mortier, P., Auerbach, R. P., Alonso, J., Bantjes, J., Benjet, C., Cuijpers, P., Ebert, D. D., Green, J. G., Hasking, P., Nock, M. K., O’Neill, S., Pinder-Amaker, S., Sampson, N. A., Vilagut, G., Zaslavsky, A. M., Bruffaerts, R., Kessler, R. C. $\&$ WHO WMH-ICS Collaborators (2018) Suicidal Thoughts and Behaviors among First-year College Students: Results from the WMH-ICS Project. Journal of American Academy Child and Adolesent Psychiatry, 57. pp. 263-273.

Nemzeti Média és Hírközlési Hatóság (2012) A média- és hírközlési biztos ajánlása az öngyilkosságokról szóló tudósításokhoz. http://nmhh.hu/media-es-hirkozlesi-biztos/ ajanlasok [Letöltve: 2017. 11. 02.]

Portzky, G. \& Van Heeringen, K. (2006) Suicide Prevention in Adolescents:

A Controlled Study of the Effectiveness of a School-based Psycho-educational Program. Journal of Child Psychology and Psychiatry, 47, pp. 910-918.

Rinmer Z. \& Fekete S. (2012) Öngyilkosság és öngyilkossági kísérlet. Öngyilkossági rizikó és protektív faktorok. In: Kalmár S., Németh A. \& Rihmer Z. (eds) Az öngyilkosság orvosi szemmel. Budapest, Medicina. pp. 91-112.

Rihmer A., Szilágyi S., Rózsa S., Gonda X., Faludi G. \& Rihmer Z. (2009) A gyermekkori abúzusok szerepe a felnőttkori szuicid magatartás kialakulásában. Neuropsychopharmacologia Hungarica, 11, pp. 237-246.

Schmidtke, A. \& Schaller, H. (2000) The Role of Mass Media in Suicide Prevention. In: K. Hawton \& K. Van Heeringen (eds) The International Handbook of Suicide and Attempted Suicide. Wiley. pp. 675-697.

Scott, M. A., Wilcox, H. C., Schonfeld, I. S., Davies, M., Hicks. R. C., Turner. J. B. \& Shaffer, D. (2009) School-based Screening to Identify At-Risk Students Not Already Known to School Professionals: The Columbia Suicide Screen. American Journal of Public Health, 99, pp. 334-339.

Szánto, K., Kalmár, S., Hendin, H., Rihmer, Z. \& Mann, J. J. (2007) A Suicide Prevention Program in a Region with a Very High Suicide Rate. Archives of General Psychiatry, 64, pp. 914-920.

Vijayakumar, L. \& Armson, S. (2005) Volunteer Perspectives on Suicide Prevention. In: K. Hawton (ed.) Prevention and Treatment of Suicidal Behaviour: From Science to Practice. Oxford, Oxford University Press. pp. 335-349.

Wasserman, C., Hoven, C. W., Wasserman, D., Carli, V., Sarchiapone, M., AlHalabi, S., Apter, A., Balazs, J., Bobes, J., Cosman, D., Farkas, L., Feldman, D., Fischer, G., Graber, N., Haring, C., Herta, D. C., Iosue, M., Kahn, J. P., Keeley, H., Klug, K., McCarthy, J., Tubiana-Potiez, A., Varnik, A., Varnik, P., Ziberna, J. \& Postuvan, V. (2012) Suicide Prevention for Youth - A Mental Health Awareness Program: Lessons Learned from the Saving and Empowering Young Lives in Europe (SEYLE) Intervention Study. BMC Public Health, 12, 776.

Wasserman, D., Hoven, C. W., Wasserman, C., Wall, M., Eisenberg, R., Hadlaczky, G., Kelleher, I., Sarchiapone, M., Apter, A., Balazs, J., Bobes, J., 
Brunner, R., Corcoran, P., Cosman, D., Guillemin, F., Haring, C., Iosue, M., Kaess, M., Kahn, J. P., Keeley, H., Musa, G. J., Nemes, B., Postuvan, V., Saiz, P., Reiter-Theil, S., Varnik, A., Varnik, P. \& Carli, V. (2015) School-based Suicide Prevention Programmes: The SEYLE Cluster-Randomised, Controlled Trial. Lancet, 385, pp. 1536-1544.

WHO (2018) Mental Health: Suicide Prevention. http://www.who.int/mental_health/ suicide-prevention/en/ [Letöltve: 2018. 07.22.]

A cikk a Creative Commons Attribution 4.0 International License (https://creativecommons.org/licenses/ by/4.0/) feltételei szerint publikált Open Access közlemény, melynek szellemében a cikk bármilyen médiumban szabadon felhasználható, megosztható és újraközölhető, feltéve, hogy az eredeti szerző és a közlés helye, illetve a CC License linkje és az esetlegesen végrehajtott módosítások feltüntetésre kerülnek. (SID_1) 